Jurnal Kesehatan Masyarakat
http://journal.unnes.ac.id/nju/index.php/kemas

\title{
KARAKTER GIZI REMAJA PUTRI URBAN DAN RURAL DI PROVINSI JAWA TENGAH
}

Vilda Ana Veria Setyawati ${ }^{\bowtie}$, Maryani Setyowati.

Fakultas Kesehatan, Universitas Dian Nuswantoro, Semarang, Indonesi

\section{Info Artikel}

Sejarah Artikel:

Diterima 9 April 2015

Disetujui 2 Juli 2015

Dipublikasikan Juli 2015

Keywords:

Nutritioonal characters;

Young women; Urban; Rural

\section{DOI}

http://dx.doi.org/10.15294/

kemas.v11i1.3463

\begin{abstract}
Abstrak
Sejak tahun 2010 westernisasi menjadi kiblat remaja dalam berbagai bidang, diantaranya gaya hidup dan perilaku makan baik di daerah urban maupun rural. Penelitian ini bertujuan untuk mengetahui perbedaan karakter gizi pada antara remaja putri urban dan rural. Rancangan cross sectional digunakan untuk mengumpulkan data dalam variabel karakter remaja gizi remaja putri urban dan rural. Lokasi penelitian ini di Kota Semarang dan Kabupaten Sragen. Responden yang diambil dari masing-masing wilayah sejumlah 48 orang. Pengumpulan data dengan wawancara menggunakan kuesioner terstruktur untuk variabel body image, pengetahuan gizi, dan perilaku makan. Instrumen untuk mengetahui status gizi adalah digital scale dan mocrotoise dan dikategorikan berdasarkan kategori Asia. Penelitian dilakukan selama Bulan Agustus dan September 2014. Analisis data menggunakan software SPSS. Uji statistik yang digunakan adalah independent $t$ test dan mann whitney untuk mengetahui perbedaan karakter gizi pada remaja urban dan remaja rural. Hasil penelitian menunjukkan bahwa tidak ada perbedaan pada body image $(\mathrm{p}=0,28)$, pengetahuan gizi $(\mathrm{p}=0,87)$, dan perilaku makan $(\mathrm{p}=0,14)$, sedangkan pada status gizi ada perbedaan $(\mathrm{p}=0,0001)$.
\end{abstract}

\section{YOUNG WOMEN NUTRITIONAL CHARACTERS AT URBAN AND RURAL IN CENTRAL JAVA}

\begin{abstract}
Since 2010 westernization be the center of a teenager in a her life, including lifestyle and eating behavior in both urban and rural areas. This study aims to determine the difference between the character of nutrition in urban and rural adolescent girls. Cross-sectional design was used to collect data in the variable character teenage girls nutrition urban and rural. The location of this research in Semarang City and Sragen. Respondents were drawn from each region some 48 people. Collecting data by interviews using a structured questionnaire for variable body image, nutrition knowledge and eating behavior. The instrument to determine the nutritional status were a digital scale and mocrotoise. Nutritional status categorized Asian. The study was conducted during the months of August and September 2014. Data were analyzed using SPSS software. The statistical test used was the independent $t$ test and Mann Whitney to determine differences in the character of nutrition in adolescents urban and rural adolescents. The results showed that there was no difference in body image $(p=0.28)$, nutritional knowledge $(p=0.87)$, and eating behavior $(p=0.14)$, whereas this got difference in nutritional status $(p=0,0001)$.
\end{abstract}

(C) 2015 Universitas Negeri Semarang 


\section{Pendahuluan}

Remaja putri mengalami percepatan pertumbuhan lebih cepat dibandingkan remaja pria, karena tubuhnya memerlukan persiapan menjelang usia reproduksi, seperti menstruasi dan kehamilan. Mereka memiliki rasa keingintahuan yang tinggi dan lebih mudah terpengaruh oleh hal-hal baru. Pengaruh yang paling besar berasal dari kelompok teman-teman sebayanya. Karena kurangnya pengetahuan di bidang gizi, sehingga munculah body image negatif dan perilaku makan yang belum sesuai dengan gizi seimbang. Remaja putri yang sehat tercermin dari karakter gizi yang sehat. Salah satu yang utama adalah karakter gizi yang meliputi body image, pengetahuan gizi, perilaku makan, dan status gizi. Remaja putri merupakan periode kritis yang harus selalu dipantau kesehatannya. Alasan utama yang menjadi dasar adalah remaja putri akan menjadi seorang ibu yang melahirkan anak, sehingga diharapkan dapat dilahirkan anak-anak yang berkualitas dari ibu yang sehat.

Sejak tahun 2010, westernisasi menjadi kiblat remaja dalam berbagai bidang, diantaranya gaya hidup dan perilaku makan. Salah satu negara yang menjadi kiblat remaja adalah Korea. Dengan masuknya "Korean wave" atau demam korea, remaja-remaja mengidolakan tokoh-tokoh penyanyi dan artis dari negara tersebut. Mereka berusaha untuk meniru apa yang melekat pada artis Korea, yaitu tubuh yang super langsing. Sehingga muncul body image negatif di kalangan remaja, bahwa tubuh yang ideal adalah tubuh yang super langsing. Demi mendapatkannya, remaja rela melakukan diet ketat tanpa disertai pengetahuan gizi yang cukup, sehingga muncullah perilaku makan yang tidak sesuai dengan prinsip-prinsip gizi. Apabila hal ini diteruskan, akan berpengaruh pada kualitas kesehatan dan gizi remaja yang seharusnya disiapkan dengan matang sebagai seorang calon ibu.

Penelitian di Semarang tahun 2008, ada $25 \%$ remaja dengan jenjang pendidikan SMA, memiliki status gizi di bawah normal. Pada penelitian yang sama juga didapatkan data bahwa sebesar $48,9 \%$ remaja putri memiliki pengetahuan gizi yang kurang. Sebaliknya pada tahun 2011 berdasarkan hasil penjaringan peserta didik TA 2011/2012 pada remaja usia 16 tahun dari 16.579 anak, sebesar 3,71\% berstatus gizi lebih (Aini, 2012). Akibat yang berlanjut ke depannya, status gizi lebih akan menjadi obesitas. Penelitian lain yang juga dilakukan di Semarang tahun 2013 pada remaja di salah satu Universitas swasta di Jawa Tengah menunjukkan bahwa $41 \%$ remaja berstatus gizi tidak normal (Matin, 2013).

Body image negatif atau persepsi citra tubuh yang buruk merupakan gangguan serius yang dapat berpengaruh pada kesehatan mental, perilaku makan dan keterbatasan aktifitas fisik. Body image negatif dapat mendorong seseorang melakukan perilaku kontrol berat badan yang tidak sehat dan eating disorder. Pengetahuan gizi memegang peranan penting dalam penggunaan pangan. Semakin tinggi pengetahuan gizi seseorang, maka akan semakin memperhitungkan jenis dan jumlah makanan yang dipilih untuk dikonsumsi. Tingkat pengetahuan gizi seseorang berpengaruh terhadap sikap dan perilaku dalam memilih makanan, yang menentukan mudah tidaknya seseorang memahami manfaat kandungan gizi dari makanan yang dikonsumsi. Dengan sikap dan perilaku makan yang kurang baik akan mengakibatkan status gizi yang kurang bagi remaja tersebut.

Sebuah provinsi terdiri dari daerah perkotaan (urban) dan daerah pedesaan (rural). Remaja yang tinggal dikedua wilayah tersebut tentunya memiliki karakter yang berbeda. Dalam kasus ini terkait dengan akses informasi, remaja urban lebih cepat melakukan akses terhadap informasi dibanding remaja yang tinggal di wilayah rural, sehingga remaja urban lebih cepat menerima westernisasi yang sudah dijelaskan di atas dan lebih dahulu juga menjadi pengikutnya. Akan tetapi survei kualitatif singkat yang dilakukan pada beberapa remaja yang tinggal di rural, dengan bekal berupa alat komunikasi canggih seperti handphone, baik remaja urban maupun rural, memiliki idola yang sama yaitu artis cantik dengan tubuh super langsing. Akibatnya, terjadi penyimpangan karakter gizi pada mereka.

Tujuan dari penelitian ini adalah mengetahui perbedaan karakter gizi antara remaja urban dan remaja rural, dengan 
mengukur nilai body image, pengetahuan gizi dan perilaku gizi, serta menghitung status gizi masing-masing.

\section{Metode}

Penelitian ini merupakan penelitian kuantitatif yang membandingkan dua kelompok sampel penelitian dengan rancangan cross sectional. Populasi penelitian ini adalah remaja putri di Provinsi Jawa Tengah. Lokasi penelitian ini di Kota Semarang dan Kabupaten Sragen. Semarang merupakan kota dengan pertumbuhan ekonomi yang cepat karena mobilitas tinggi dan terletak di wilayah pantai utara sehingga karakter remaja putri lebih mudah terpapar westernisasi. Sedangkan Sragen merupakan kabupaten yang memiliki suasana desa dengan karakter remaja yang masih sedikit terpengaruh westernisasi. Responden yang diambil dari masing-masing wilayah sejumlah 48 orang, sehingga totalnya sejumlah 96 orang. Pengambilan responden dengan teknik simple random sampling. Kriteria responden yaitu usia 16-21 tahun, aktif sebagai siswa SMA, menetap dan tercatat sebagai warga di wilayah penelitian, tidak menderita penyakit kronis. Pengumpulan data primer dengan wawancara menggunakan kuesioner terstruktur untuk variabel body image, pengetahuan gizi, dan perilaku makan. Hasil dari pengisian kuesioner diberikan penilaian dan dikategorikan. Kategori body image dibagi menjadi dua yaitu puas (>mean skor $\mathrm{T}$ standar) dan tidak puas ( $<$ mean skor $\mathrm{T}$ satndar).Kategori pengetahuan gizi yaitu baik (>80\% jawaban benar), cukup (60-80\% jawaban benar), kurang ( $<60 \%$ jawaban benar). Kategori perilaku makan yaitu sudah menjalankan perilaku makan yang baik (total skor $\geq$ $80 \%$ jawaban benar dari seluruh item yang ditanyakan) dan belum menjalankan perilaku makan yang baik(total skor $<80 \%$ jawaban benar dari seluruh item yang ditanyakan). Kuesioner yang dipakai sebagai instrumen penelitian sudah melewati uji validitas dan reliabilitas pada 20 responden. Sedangkan instrumen untuk mengetahui status gizi adalah digital scale dan mocrotoise dan dihitung indeks massa tubuhnya lalu dikategorikan berdasarkan kategori Asia. Penelitian dilakukan selama Bulan Agustus dan September 2014. Analisis data menggunakan software SPSS. Uji statistik yang digunakan adalah independent $t$ test dan mann whitney untuk mengetahui perbedaan karakter gizi pada remaja urban dan remaja rural.

Tabel 1. Distribusi Responden Menurut Karakteristik Individu

\begin{tabular}{|c|c|c|c|c|c|c|c|c|}
\hline \multirow{2}{*}{ No } & \multirow{2}{*}{$\begin{array}{c}\text { Karakteristik } \\
\text { gizi }\end{array}$} & \multirow{2}{*}{$\begin{array}{c}\text { Rerata } \\
\text { total }\end{array}$} & \multicolumn{2}{|r|}{ Kota } & \multicolumn{2}{|c|}{ Rural } & \multirow[b]{2}{*}{ rerata } & \multirow{2}{*}{$\begin{array}{c}\text { Uji } \\
\text { beda }\end{array}$} \\
\hline & & & $\mathbf{n}$ & $\%$ & $\mathbf{n}$ & $\%$ & & \\
\hline \multirow[t]{5}{*}{1} & Status gizi & $19,8 \pm 3,3$ & \multicolumn{4}{|c|}{$19,08 \pm 3,5$} & $21,07 \pm 2,9$ & $0,0001^{\mathrm{a}}$ \\
\hline & Gizi kurang & & 23 & 47,9 & 9 & 18,8 & & \\
\hline & Normal & & 20 & 41,2 & 27 & 56,2 & & \\
\hline & Overweight & & 3 & 6,2 & 6 & 12,5 & & \\
\hline & Obesitas & & 2 & 4,2 & 5 & 10,4 & & \\
\hline \multirow[t]{3}{*}{2} & Body image & $50,7 \pm 0,001$ & \multicolumn{4}{|c|}{$50,9 \pm 9,2$} & 48,6 & $0,28^{\mathrm{b}}$ \\
\hline & Puas & & 37 & 77,1 & 17 & 35,4 & & \\
\hline & Tidak puas & & 11 & 22,9 & 31 & 64,6 & & \\
\hline \multirow[t]{4}{*}{3} & Pengetahuan gizi & $66,7 \pm 12,4$ & \multicolumn{4}{|c|}{$66,3 \pm 13,2$} & $66,1 \pm 11,7$ & $0,87^{\mathrm{b}}$ \\
\hline & Baik & & 8 & 16,7 & 6 & 12,5 & & \\
\hline & Cukup & & 25 & 52,1 & 30 & 62,5 & & \\
\hline & Kurang & & 15 & 31,2 & 12 & 25 & & \\
\hline \multirow[t]{3}{*}{4} & Perilaku makan & $43,5 \pm 8,2$ & \multicolumn{4}{|c|}{$44,8 \pm 7,01$} & $43,2 \pm 9,2$ & $0,14^{\mathrm{b}}$ \\
\hline & Baik & & 0 & 0 & 0 & & & \\
\hline & Belum baik & & 48 & 100 & 48 & & 100 & \\
\hline
\end{tabular}

Sumber : data primer

${ }^{a}$ independent $t$ test

${ }^{b}$ mann whitney 
Tabel 2. Tabulasi Silang Antara Body Image dan Status Gizi

\begin{tabular}{llccccc}
\hline \multirow{2}{*}{ Variabel } & & \multicolumn{4}{c}{ Status gizi } & \multirow{2}{*}{ Total } \\
\cline { 2 - 6 } & & Underweight & Normal & Overweight & Obesitas & \\
\hline \multirow{3}{*}{ Body image } & Tidak puas & 1 & 17 & 7 & 3 & 28 \\
\cline { 2 - 7 } & & $1,0 \%$ & $17,7 \%$ & $7,3 \%$ & $3,1 \%$ & $23,2 \%$ \\
\cline { 2 - 7 } & Puas & 33 & 29 & 2 & 4 & 68 \\
\hline \multirow{2}{*}{ Total } & $34,4 \%$ & $30,2 \%$ & $2,1 \%$ & $4,2 \%$ & $70,8 \%$ \\
\hline & & 34 & 46 & 9 & 7 & 96 \\
\hline
\end{tabular}

Sumber : data primer

\section{Hasil dan Pembahasan}

Remaja adalah satu dari beberapa golongan yang termasuk golongan rentan gizi. Pada kelompok umur tersebut berada pada suatu siklus pertumbuhan atau perkembangan yang memerlukan zat-zat gizi dalam jumlah yang lebih besar dari kelompok umur yang lain. Menurut Notoatmojo (2003), pertumbuhan anak remaja juga sangat pesat kemudian kegiatan-kegiatan jasmani termasuk olahraga juga pada kondisi puncaknya. Oleh sebab itu, apabila konsumsi makanan tidak seimbang dengan kebutuhan kalori untuk pertumbuhan dan kegiatan-kegiatannya maka akan terjadi defisiensi yang akhirnya dapat menghambat pertumbuhannya. Masalah gizi pada remaja akan berdampak negatif pada tingkat kesehatan masyarakat, misalnya penurunan konsentrasi belajar, risiko melahirkan bayi dengan BBLR, penurunan kesegaran jasmani. Banyak penelitian telah dilakukan menunjukkan kelompok remaja menderita/mengalami banyak masalah gizi. Masalah gizi tersebut antara lain Anemi dan IMT kurang dari batas normal atau kurus. Prevalensi anemi berkisar antara $40 \%-88 \%$, sedangkan prevalensi remaja dengan IMT kurus berkisar antara 30\%-40\%. Banyak faktor yang menyebabkan masalah ini. Dengan mengetahui faktor-faktor penyebab yang mempengaruhi masalah gizi tersebut membantu upaya penanggulangannya dan lebih terpengaruh dan terfokus.

Berdasarkan data Tabel 1, terdapat perbedaan antara remaja urban dan rural pada variabel status gizi $(\mathrm{p}=0,0001)$. Rerata status gizi pada remaja putri urban sebesar $19,08 \pm 3,5$, dimana nilai ini lebih rendah dibanding remaja putri rural yaitu $21,07 \pm 2,9$. Namum keduanya masih termasuk dalam status gizi normal. Rerata body image pada remaja urban yaitu
$50,9 \pm 9,2$, sedangkan pada remaja putri rural 48,6 . Rerata pengetahuan gizi pada remaja putri urban sebesar $66,3 \pm 13,2$ dan remaja putri rural sebesar $66,1 \pm 11,7$. Rerata perilaku makan remaja putri urban sebesar 44,8 $\pm 7,01$ dan remaja putri rural sebesar $43,2 \pm 9,2$. Walaupun dilihat dari rerata menunjukkan perbedaan ketiga karakter gizi antara kedua kelompok, tetapi tidak terlihat adanya perbedaan pada ketiga variabel karakter gizi ( $p>0,05)$.

Ukuran keberhasilan seseorang dalam menerapkan gizi seimbang adalah status gizi. Tidak hanya itu saja, penilaian kesehatan pertama secara klinis adalah ukuran badannya. Orang yang terlalu kurus ataupun terlalu gendut cenderung berkorelasi dengan memiliki suatu gangguan kesehatan. Hasil yang berbanding terbalik ditunjukkan pada Tabel 1, sebagian remaja urban mengalami "underweight" $(47,9 \%)$ dan sebagian remaja rural justru gizi normal $(59,2 \%)$. Dengan demikian, justru ada kemungkinan terjadi pergeseran pengertian karakter gizi yang ideal menurut remaja putri urban. Hal ini sangat ironis apabila mengingat remaja kota biasanya identik dengan kemudahan mengakses informasi dibandingkan remaja rural. Beberapa literatur menjelaskan bahwa justru dengan kemudahan akses informasi, remaja kota terpapar beberapa informasi yang kurang tepat mengenai diet, sehingga ditemukan jumlah remaja gizi kurang lebih banyak.

Hasil yang berkebalikan ditunjukkan pengukuran body image, yaitu pada remaja kota sebagian besar merasa puas $(77,1 \%)$ dengan bentuk tubuhnya, sedangkan remaja rural sebagian besar $(64,6 \%)$ merasa tidak puas dengan bentuk tubuhnya. Sehingga secara garis besar remaja yang normal tidak puas dengan bentuk tubuhnya, tetapi remaja yang 
gizi kurang justru merasa tidak puas dengan bentuk tubuhnya (Tabel 2). Padahal seharusnya remaja putri berstatus gizi normal agar kualitas hidupnya lebih baik. Dengan kualiatas hidup yang baik diharapkan akibat prestasinya juga baik.

Hasil pengukuran variabel pengetahuan gizi menunjukkan bahwa sebagian besar memiliki pengetahuan yang cukup, remaja putri kota $(52,1 \%)$ dan remaja rural $(62,5 \%)$. Akan tetapi memiliki pengetahuan yang cukup belum tentu perilaku makan yang dilakukan sudah baik. Hasil menunjukkan perilaku makan baik semua remaja putri rural maupun kota belum menjalankan perilaku makan dengan baik (100\%) (Tabel 1).

Periode remaja adalah masa transisi atau peralihan dari periode anak-anak ke periode dewasa. Ada beberapa karakteristik yang melekat pada diri seorang remaja pada umumnya, yaitu karakter fisiologis dan psikologis. Dari sisi fisiologis, remaja putri akan mengalami pubertas yang menyebabkan munculnya tanda seks sekunder, yaitu payudara mulai membesar, kulit mejadi lebih halus, pertumbuhan pinggul yang membesar, tinggi bertambah, dan suara lebih halus. Dari sisi psikologis, remaja mengalami puncak emosionalitasnya. Perkembangan emosi remaja pada tahap awal menunjukkan sisi sensitif, reaktif, emosinya bersifat negatif dan temperamental. Sedangkan remaja akhir sudah mulai mampu mengendalikan sifatsifat tersebut. Remaja yang berkembang di lingkungan yang kurang kondusif, cenderung memiliki kematangan emosi yang kurang. Sehingga sering memunculkan akibat negatif berupa tingkah laku melawan, keras kepala, berkelahi, suka menggangu, suka melamun, pendiam, senang menyendiri, mengkonsumsi obat penenang, minuman keras, atau obat terlarang. Sedangkan remaja yang tinggal di lingkungan yang kondusif dan harmonis dapat membantu kematangan emosi remaja menjadi memiliki cinta, kasih sayang, simpati, altruis, menghormati orang lain, tidak mudah tersinggung, tidak agresif, wajar, optimistik, menghadapi kegagalan secara sehat dan bijak. Usia remaja berkisar dari usia 13 tahun sampai 21 tahun, terbagi menjadi 3 tahap yaitu (1) remaja awal (13-14 tahun), (2) remaja tengah (15-17 tahun), (3) remaja akhir (18-21 tahun) (Dariyo A, 2004). Pengamatan secara kualitatif, remaja awal memiliki kesamaan sebagian sifat seperti anak-anak, remaja akhir sudah memiliki sifat mendekati orang dewasa, sedangkan remaja tengah merupakan masa remaja yang memiliki sifat paling murni sebagai seorang remaja.Berdasarkan sifat-sifat remaja tersebut, mereka menciptakan pola makan bukan bertujuan untuk memenuhi gizi tetapi hanya untuk sekedar sosialisasi agar tidak kehilangan status. Remaja melakukannya untuk kesenangan agar bisa berinteraksi dengan teman sebayanya tanpa memikirkan gizi dan dampaknya bagi tubuh mereka.

Kebiasaan makan yang kurang baik pada remaja dan keinginan untuk terlihat langsing, seringkali menimbulkan gangguan makan (eating disorder). Gangguan pola makan yang umum diderita khususnya oleh remaja putri adalah bulimia dan anorexsia nervosa. Pada remaja putri ini pada umumnya ingin mempunyai bentuk badan yang lebih langsing, ramping dan menarik walaupun itu tidak normal. Untuk mencapai hal tersebut mereka tidaksegan-segan melakukan hal-halyangjustru tidak mereka sadari dapat membahayakan diri dan kesehatannya. Agar tampak langsing dan menarik mereka tidak meninggalkan makan pagi, mengurangi frekuensi makan bahkan melakukandiet yang berlebihan. Hampir $50 \%$ remaja terutama remaja tengah, tidak sarapan. Penelitian lain membuktikan masih banyak remaja sebesar $89 \%$ yang meyakini kalau sarapan memang penting, namun yang sarapan secara teratur hanya $60 \%$. Remaja putri malah melewatkan dua kali waktu makan, dan lebih memilih makanan ringan.

Terobsesi menjadi langsing bahkan tidak mengkonsumsi makanan sama sekali akan membuat masalah bagi diri sendiri. Hal ini tidak berkaitan dengan makanan yang dikonsumsi namun penilaian terhadap diri sendiri yang mengakibatkan munculnya pola makan yang tidak sesuai gizi seimbang. Akan tetapi, setelah menjadi langsing tidak akan menghentikan pola makan tidak sehat ini jika mereka tidak menyukai dirinya sendiri. Orang tua perlu waspada akan hal ini, bantulah agar fakta ini disadari dan jelaskan bahwa hal yang mereka lakukan untuk mendapatkan tubuh 
yang ramping tanpa dasar yang benar memiliki resiko kesehatan. Jika keadaan ini memburuk orang tua memerlukan pendampingan dokter dan konselor supaya tidak memperburuk keadaan yang dialami anak.

Komposisi tubuh antara remaja putri dan putra tidaklah sama. Remaja putra cenderung mengembangkan massa ototnya, sedangkan remaja putri mengembangkan lemak tubuhnya $1,5-2$ kali lebih banyak daripada otot tubuh. Kecenderungan yang terjadi pada perkembangan komposisi tubuh ini menyebabkan persepsi body image yang berbeda pada mereka. Hasil penelitian juga menyebutkan kebanyakan remaja putra ingin menaikan berat badan, sedangkan remaja putri ingin menurunkan berat badan. Persepsi remaja ini terbentuk akibat gaya hidup sehingga mengakibatkan pola makan remaja yang tidak sesuai dengan diet yang seimbang.

Body image merupakan gabungan dari sikap dan persepsi seseorang terhadap tubuhnya dan gambaran mental yang seseorang miliki tentang tubuhnya yang meliputi dua komponen. Kedua komponen body image yang dimaksud adalah komponen perseptual (meliputi ukuran, bentuk, berat badan, karakteristik, gerakan, dan tampilan tubuh) dan komponen sikap (apa yang dirasakan tentang tubuh dan bagaimana perasaan ini mengarahkan pada tingkah laku). Arah body image dipengaruhi oleh banyak hal, dan yang paling utama yaitu lingkungan. Remaja putri umumnya memiliki body imageke arah negatif. Penelitian ini menunjukkan bahwa remaja lebih puas apabila tubuhnya kurang gizi (Tabel 2).

Seperti yang sudah dijelaskan di atas, sejak tahun 2010 fenomena "girl band" sangat menjamur di kalangan remaja dengan kiblat girl band Korea. Mereka menjadi sosok idola remaja putri masa kini. Sehingga memunculkan persepsi bahwa kecantikan seorang perempuan adalah seperti mereka yang memiliki tubuh tinggi, kaki kecil panjang, badan super langsing, wajah tirus, dan perut rata. Apabila dilihat sekilas, orang-orang yang ada di girl band ini termasuk dalam golongan "underweight". Muncullah pertanyaan, bagaimana seorang remaja bisa mengidolakan mereka? Jawabannya adalah mudahnya mengakses informasi baik remaja urban maupun rural dengan handphone yang dilengkapi berbagai aplikasi. Bahkan sampai mengubah sesuatu yang positif menjadi negatif, yaitu remaja rural yang sebagian besar memiliki status gizi normal, justru tidak puas dengan bentuk tubuhnya sekarang (tabel 2). Penelitian ini tidak menjelaskan apakah remaja di rural tersebut tidak puas karena ingin menambah berat badan atau mengurangi berat badannya. Akan tetapi, melihat fenomena pada remaja putri, kemungkinan besar mereka ingin mengurangi berat badannya. Belum lagi ditambah pengaruh "peer group" di lingkunganya sekolah. Hubungan persahabatan secara emosional menyediakan keamanan dan kenyamanan bagi remaja putri untuk saling berbagi informasi. Pada umumnya hubungan sesama teman juga membentuk cara pandang yang sama terhadap suatu hal, khususnya pendapat tentang tubuh ideal. Sehingga memunculkan "appearance comparison" yaitu membanding-bandingkan bentuk tubuhnya denganteman sebayanya. Tingkat pentingnya bentuk tubuh "ideal" (dalam persepsi mereka) berada pada kategori tinggi yang menyebabkan remaja putri ini berusaha untuk mendapatkannya dengan cara apapun.

Selain westernisasi, pengaruh media audiovisual juga berkontribusi besar dalam karakter gizi remaja putri. Banyaknya sinetron remaja, media massa, fashion dan produk kesehatan juga turut serta dalam mendukung citra tubuh yang bebas gemuk, bahkan hampir menyerupai barbie. Menurut Tambunan (2002), penilaian citra tubuh pada remaja dibentuk berdasarkan pengalaman yang didapat orang tua, public figure dan teman sekelompok yang memberikan gagasan tentang nilai dari sebuah tubuh Sehingga, sebagian besar remaja beranggapan bahwa mereka akan mendapatkan kepercayaan diri yang tinggi apabila mereka memiliki tubuh yang sempurna, seperti halnya remaja yang ingin terlihat langsing dan kurus karena mereka beranggapan bahwa menjadi kurus akan membuat mereka bahagia, sukses dan populer (Tambunan, 2002).

Beberapa cara dilakukan untuk mendapatkan bentuk tubuh ideal, salah satunya adalah diet. Arti istilah diet yang benar menurut ilmu gizi adalah mengatur jumlah makanan yang dikonsumsi sesuai dengan kebutuhan energi harian. Tentunya apabila 
kurang gizi jumlah energi harus ditambah, dan sebaliknya apabila gizi lebih jumlah energi harus dikurangi. Kebutuhan gizi masing-masing individu tidak sama, tergantung dari beberapa hal. Diantaranya jenis kelamin, aktivitas fisik, dan umur. Tentunya antara remaja putri dan putra, lebih banyak remaja putra. Akan tetapi, istilah diet yang beredar di kalangan remaja putri adalah membatasi makanan. Arahnya adalah meminimalkan makanan yang masuk. Bahkan ada yang melakukan diet ekstrim sehari hanya makan buah saja. Akibatnya tubuh akan kekurangan gizi walaupun pada akhirnya tubuh "ideal" yang mereka inginkan tercapai. Perilaku makan seperti ini mengarah kepada kelainan makan "anoreksia nervosa". Akibat jangka panjang dari diet ini adalah tubub sudah terbiasa menolak makanan, sehingga tidak hanya kurang gizi derajat ringan, tetapi juga kurang gizi derajat berat.

Peran pengetahuan gizi pada kasus masalah gizi remaja putri sangat penting. Sebenarnya baik pada remaja urban dan rural, sebagian besar memiliki pengetahuan yang cukup yang masing-masing $52,1 \%$ dan $62,5 \%$ (Tabel 1) sehingga perilaku diet yang buruk bisa dicegah dengan pendampingan dari lingkungan,baik lingkungan keluarga maupun sekolah. Apabila dilihat, remaja rural justru memiliki pengetahuan yang cukup lebih banyak. Sehingga menepis anggapan bahwa remaja rural memiliki akses informasi kurang dibanding remaja urban. Kemajuan teknologi yang sangat pesat dewasa ini telah mengubah kehidupan masyarakat di semua wilayah. Teknologi yang semakin mutakhir tersebut menawarkan berbagai kemudahan serta gaya hidup baru yang terkadang justru meninggalkan pola pola lama yang bersifat tradisional. Manusia jaman sekarang tergantung dengan $\mathrm{TV}$, radio, surat kabar, juga internet, terbukti dengan menjamurnya warung-warung internet baik di kota besar maupun kota-kota kecil. Dengan biaya yang relatif murah dunia dapat dijelajah di depan monitor. Remaja putri rural maupun urban, memiliki kemudahan akses informasi melalui media sosial.Media sosial adalah wahana komunikasi atau pertukaran informasi yang telah terpola dalam kehidupan sosial suatu komunitas masyarakat. Media sosial menuntut keterlibatan secara fisik individu dalam proses komunikasi. Media sosial menggunakan komunikasi tatap muka dalam bentuk komunikasi antar personal maupun komunikasi kolektif. Disini proses keterlibatan anggota menjadi sangat krusial. Media rakyat ini digambarkan sebagai media yang murah, mudah, bersifat sederajat, dialogis, sesuai dan sah dari segi budaya, bersifat setempat, lentur menghibur dan sekaligus memasyarakat juga sangat dipercayaoleh kalangan masyarakat rural yang kebetulan menjadi kelompok sasaran utama. Jenis media sosial setiap tahun bertambah dengan kelebihan dan kekurangannya masing-masing.

Perilaku makan remaja urban dan rural menunjukkan hasil negatif, artinya semua remaja yang menjadi responden penelitian ini belum menjalankan perilaku makan baik sesuai pesan umum gizi seimbang (Tabel 1). Seharusnya ada korelasi positif antara pengetahuan yang cukup dengan perilaku makan yang positif. Ada bebepa faktor di luar penelitian yang mempengaruhi perilaku makan remaja putri. Perilaku merupakan suatu kegiatan atau aktivitas seseorang. Perilaku kesehatan pada dasarnya adalah suatu respon seseorang terhadap stimulas yang berkaitan dengan sakit dan penyakit, sistem pelayanan kesehatan, makanan serta lingkungan. Teori perilaku yang selalu menjadi dasar penelitian kesehatan adalah Teori Blum, yang menyatakan ada 4 faktor yang mempengaruhi derajat kesehatan pada manusia yaitu genetik (hereditas), lingkungan, pelayanan kesehatan, dan perilaku. Perilaku makan adalah cara seseorang berpikir, berpengetahuan dan berpandangan tentang makananApayang ada dalam perasaan dan pandangan itu dinyatakan dalam bentuk tindakan makan dan memilih makana. Jika keadaan itu terus menerus berlangsung maka tindakan tersebutakan menjadi kebiasaan makan. Kebiasaan makan adalah tingkah laku manusia atau kelompok manusia dalam memenuhi kebutuhan akan makan yang meliputi sikap, kepercayaan dan pemilihan makanan. Kebiasaan makan akan dipengaruhi oleh beberapa hal antara lain kesenangan, budaya, agama, taraf ekonomi, lingkungan alam dan sejak dahulu makanan juga dianggap sebagai lambang kekuasaan dan persahabatan. 
Secara nasional rata-rata kecukupan konsumsi energi penduduk usia 16-18 tahun berkisar antara 69,5\% - 84,3\%, dan sebanyak 54,5 $\%$ remaja mengonsumsi energi dibawah kebutuhan minimal. Rata-rata kecukupan konsumsi protein remaja berkisar antara $88,3 \%$ - 129,6\%, dan remaja yang mengonsumsi dibawah kebutuhan minimal sebanyak $35,6 \%$. Di perkotaan, rata - rata remaja kekurangan 670 kilo kalori energi dan 1,2 gram protein. Di Sumatera Utara remaja yang mengkonsumsi energi di bawah kebutuhan minimal sebanyak $51,5 \%$ dan protein sebanyak 21,2\% (Riskesdas 2010). Dampak gangguan makan pada anak dan remaja tergantung pada berat dan lamanya gangguan makan yang terjadi. Jika gangguan terjadi dalam waktu beberapa hari saja dapat menyebabkan remaja kekurangan energi akan tetapi bila berlangsung lama dapat berakibat hambatan pertumbuhan dan perkembangan bahkan kematian.

Perilaku makan remaja adalah suatu tingkah laku, yang dapat dilihat dan diamati, yang dilakukan oleh remaja dalam rangka memenuhi kebutuhan makan yang merupakan kebutuhan fisiologis dasar. Hal ini merupakan reaksi terhadap stimulus yang berasal dari dalamdirinya dan juga dari luar dirinya. Jadi, dapat dikatakan bahwa perilaku makan menjadi kebutuhan untuk menunjukkan eksistensinya sebagai makhluk hidup serta sebagai dasar guna melakukan interaksi dengan orang lain. Perilaku makan tidak baik yang sering dilakukan remaja meliputitidak makan terutama makan pagi atau sarapan, kegemaran makan snacks dan kembang gula serta soft drinks. Makanan kecil umumnya dikonsumsi pada waktu sore hari setelah pulang dari sekolah, makanan cepat saji sangat digemari, baik yang langsung dibeli atau makanan yang dibawa dari rumah makanan modern ini dikonsumsi sebagai bagian dari life style (gaya hidup). Makanan ini mengandung zat gizi yang tinggi energi, lemak, serta protein, gemar mengonsumsi minuman ringan (soft drink). Banyak remaja memiliki kebiasaan tidak sarapan pagi. Mereka sering menggantikan makan pagi dengan makan siang yang berlebih atau memakan makanan kecil yang tinggi lemak dan kalori dalam jumlah yang relatif banyak. Ada sekitar 60\% anak Indonesia tidak sarapan pagi sebelum berangkat kesekolah dan itu menjadi perhatian penuh, sebab sarapan pagi akan memberikan kontribusi penting akan beberapa zat gizi yang diperlukan tubuh seperti protein, lemak, vitamin dan mineral. Selain kebiasaan tidak sarapan pagi, saat ini remaja lebih menyukai mengonsumsi makanan jajanan siap saji (fast food). Orang tua mempunyai peranan penting dalam membentuk kebiasaan makananak-anak, khususnya sewaktu masih usia balita. Pada waktu anak menginjak usia remaja, kebiasaan makan dipengaruhi oleh lingkungan, teman sebaya, kehidupan sosial, dan kegiatan yang dilakukan di luar rumah (Field, 2001).

Kebiasaan makan keluarga mempengaruhi kebiasaan makan seorang remaja. Asupan makanan yang sudah menjadi hidangan sehari-hari, membentuk kesukaan remaja terhadap makanan sehat atau tidak sehat. Keluarga yang sering menyajikan fast food untuk anak mereka, cenderung memiliki anak-anak remaja yang memiliki pola makan yang buruk yaitu kesukaan terhadap "fast food". Dibandingkan dengan keluarga yang jarang atau tidak menyajikan makanan siap saji untuk anak remaja mereka. Ketersediaan makanan siap saji di rumah berhubungan dengan peningkatan konsumsi makanan asin dan makanan siap saji pada remaja. Hasil penelitian Endriani (2012), menyatakan bahwa tingkat pengeahuan ibu, pendidikan ibu, pendapatan keluarga, serta tingkat konsumsi energi dan protein berhubungan dengan status gizi. Secara khusus, perhatian ekstra perlu diberikan untuk remaja putri yang akan menjadi calon ibu untuk mencapai status gizi kesehatan yang optimal. Dengan status gizi yang optimal pertumbuhan dan perkembangan remaja lebih sempurna. Status gizi remaja tidak hanya dipengaruhi oleh faktor ekonomi akan tetapi dipengaruhi pula faktor budaya seperti kebiasaan makan. Kebiasaan yang buruk pada remaja memungkinkan terjadinya gizi kurang maupun obesitas. Perilaku konsumsi gizi seimbang merupakan keseimbangan zatzat gizi yang dikonsumsi oleh remaja putri dalam setiap hidangan makanan yang meliputi karbohidrat, lemak, protein, vitamin dan mineral. Untuk mendapatkan sumber daya manusia yang berkualitas adalah dengan cara meningkatkan status gizi masyarakat termasuk 
remaja putri yang tercermin dalam perilaku makan sehari-hari.

Sedikit sekali yang diketahui tentang asupan pangan remaja. Meski asupan kalori dan protein sudah tercukupi, namun elemen lain seperti besi, kalsium dan beberapa vitamin ternyata masih kurang. Penelitian terhadap masyarakat miskin di Kairo menunjukkan asupan besi sebagian besar remaja putri tidak mencukupi kebutuhan harian yang dianjurkan. Di negara yang sedang berkembang, sekitar $27 \%$ remaja lelaki dan $26 \%$ remaja putri menderita anemia, sementara di negara maju angka tersebut hanya berada pada bilangan 5\% dan $7 \%$.

Pola makan yang salah dengan tinggi lemak, karbohidrat dan protein akan meningkatkan berat badan yang lebih dan hal ini secara langsung akan meningkatkan status gizi pada kondisi lebih. Penerapan pola makan seperti ini tentunya akan meningkatkan kerja organ-organ tubuh sebagaibentuk haemodialisa (kemampuan tubuh untuk menetralisir pada keadaan semula) dalam rangka pengeluaran kelebihan tersebut. Dalam hal ini akan berdampak pada fungsi sistem hormonal pada tubuh. Adanya gangguan pada fungsi hormonal tubuh tersebut akan mempengaruhi kerja-kerja organ tubuh secara maksimal termaksud organ seksual perempuan baik berupa peningkatan progesteron, estrogen, FSH dan LH sendiri akan berdampak pada gangguan siklus haid yang terlalu panjang atau pendek.

Penelitian RIna (2008), menyatakan bahwa kebiasaan makan fast food berisiko terjadi obesitas. Kebiasaan makan yang diperoleh semasa remaja akan berdampak pada kesehatan dalam fase kehidupan selanjutnya, setelah dewasa dan berusia lanjut. Kekurangan besi dapat menimbulkan anemia dan keletihan, kondisi yang menyebabkan mereka tidak mampu merebut kesempatan bekerja. Remaja memerlukan lebih banyak besi dan wanita membutuhkan lebih banyak lagi untuk menggantikan besi yang hilang bersama haid setiap bulannya.

Salah satu hal yang paling penting yang harus dilakukan remaja agar selalu sehat bukan hanya untuk saat sekarang tetapi juga menunjang kesehatan seumur hidupnya adalah mengkonsumsi makanan yang bergizi.
Pada masa pertumbuhan tubuh remaja sangat membutuhkan protein, vitamin dan mineral. Jika remaja cukup makan, maka remaja tersebut tidak akan sakit. Ada jenis-jenis makanan tertentu yang sangat penting bagi gadis remaja. Ketika ia mulai mendapat menstruasi, tiap bulan ada sejumlah darah yang keluar. Remaja putri tersebut akan menghadapi resiko anemia yang tinggi. Pada remaja putri perlu mempertahankan status gizi yang baik, dengan cara mengkomsumsi makanan yang seimbang karena sangat dibutuhkan pada saat haid, terbukti pada saat haid tersebut terutama pada fase luteal akan terjadi peningkatan kebutuhan nutrisi. Apabila hal ini diabaikan maka dampakanya akan terjadi keluhan- keluhan yang menimbulkan rasa ketidaknyamanan selama siklus haid.

Pada uji perbedaan keempat variabel diantara kelompok kota dan rural, hanya variabel status gizi yang menunjukkan adanya perbedaan. Hal ini menjadi pertimbangan bahwa remaja putri rural maupun kota harus mendapatkan pendidikan gizi. Perlu dibuat sebuah model pendidikan gizi yang menarik karena remaja putri tersebut tidak mendapat pendidikan gizi di sekolahnya.

\section{Penutup}

Ada perbedaan status gizi, tetapi tidak ada perbedaan body image, pengetahuan gizi, dan perilaku makan antara remaja putri rural dan urban. Rerata status gizi pada remaja putri urban sebesar $19,08 \pm 3,5$, dimana nilai ini lebih rendah dibanding remaja putri rural yaitu $21,07 \pm 2,9$. Namum keduanya masih termasuk dalam status gizi normal. Rerata body image pada remaja urban yaitu 50,9 $\pm 9,2$, sedangkan pada remaja putri rural 48,6 . Rerata pengetahuan gizi pada remaja putri urban sebesar $66,3 \pm 13,2$ dan remaja putri rural sebesar $66,1 \pm 11,7$. Rerata perilaku makan remaja putri urban sebesar 44,8 $\pm 7,01$ dan remaja putri rural sebesar $43,2 \pm 9,2$. Walaupun dilihat dari rerata menunjukkan perbedaan ketiga karakter gizi antara kedua kelompok, tetapi tidak terlihat adanya perbedaan pada ketiga variabel karakter gizi $(p>0,05)$. Perilaku makan remaja putri baik rural maupun urban perlu diperbaiki dengan pendampingan orang tua dan pihak sekolah dengan alasan semua remaja putri 
belum menjalankan perilaku makan yang baik menurut pesan umum gizi seimbang.

\section{Ucapan Terima Kasih}

Ucapan terima kasih kepada Dinas

Pendidikan Provinsi Jawa Tengah yang telah membiayai penelitian ini untuk tahun anggaran 2014. Semoga memberikan manfaat untuk peningkatan kualitas kesehatan remaja putri Jawa Tengah khususnya di bidang gizi.

\section{Daftar Pustaka}

Aini, S,N. 2012. Faktor Risiko yang Berhubungan dengan Kejadian Gizi Lebih pada Remaja Perkotaan. Unnes Journal of Public Health. $1(2): 2-8$

Andriani Elisa Pahlevi. 2012. Determinan Status Gizi pada Siswa Sekolah Dasar. Jurnal Kemas, 7 (2).

Dariyo, A. 2004.Psikologi Perkembangan Remaja. Bogor : Ghalia Indonesia
Field, A.E., et al. 2001. Peer, Parent, and Media Influence On the Development of Weight Concernsand Frequent Dieting Among Preadolescent and Adolescent Girls and Boys. Pediatrics, 107, 54-60. Maret 3, 2014. http:// www.pediatrics.org

Matin, S.S., \& Setyawati, V.A.V. 2013. Body Mass Index (BMI) sebagai Salah Satu Faktor yang Berkontribusi Terhadap Prestasi Belajar Remaja (Studi pada Mahasiswa Fakultas Kesehatan Universitas Dian Nuswantoro). Jurnal Visikes 12(2) : 170-175.

Notoadmodjo, S. 2007. Promosi Kesehatan dan Ilmu Perilaku. Jakarta : Rineka Cipta.

Rina R, Oktia Woro. 2008. Kebiasaan Makan Fast Food, Konsumsi Serat, dan Status Obesitas pada Remaja Putri. Jurnal Kemas, 3(2): 185195

RISKESDAS. 2010. Riset Kesehatan Dasar Tahun 2010. Jakarta : Badan Penelitian dan

Pengembangan Kesehatan Departemen Kesehatan RI. 